\title{
Karel Nedbálek
}

\author{
JUDr., Ing., PhD., MBA, general director, Slušovice, Czech republic, e-mail: \\ slusovice@motelgolf.cz, https://orcid.org/0000-0002-1010-2460
}

\section{LICITATION SPREAD, INTERPOLATING THE CALCULATION}

\begin{abstract}
The licitation spread is calculated to determine the market price for negotiation. It is beneficial in the case of selling real estate. Theoretically, we use an interpolation method. This method looks for the value of a property to find an approximate value at some interval. It can be used if the function values at specific interval points are either given in a table or obtained by measurement.

The Occam's razor principle states that a more straightforward explanation is more likely and simplifies problem-solving access and speed. To calculate the property's price, we will use a cost method; this method is based on the costs for acquiring the item or property. A revenue method is based on the actual return per year on the property to determine the value. Finally, we apply a comparison method based on comparing the valuation subject with the same or similar character.
\end{abstract}

After the calculations and analysis have been carried out, we will reach the licitation spread where the value of the valued assets is located.

Keywords: licitation spread, property price, cost method, yield method, comparison method.

Formulation of the problem.. The licitation spread is calculated to determine the market price for negotiation. It is beneficial in the case of selling real estate. Theoretically, we use an interpolation method. This method looks for the value of a property to find an approximate value at some interval. It can be used if the function values at specific interval points are either given in a table or obtained by measurement.

If we want to set the price of a property, we must examine the problem from the point of view of:

$>$ History,

Law,

Philosophy,

Political science,

Sociology,

Psychology,

Economy.

In the following text, we will use the method of economic analysis and the 
historical method. [6] There are several ways to obtain an interpolation interval.

Analysis of recent research and publications. Research problematics of the licitation spread, in an interdisciplinary dimension, engaged in many domestic and international experts.

Purpose of the article: explore the features of the licitation spread.

The empirical method is based on an immediate, vivid experience of reality. Therefore, it is a method by which it is possible to determine an object or phenomenon's specific unique characteristics. Usually, this method is divided into subgroups according to the way they are implemented. Commonly used are:

- Observation,

- Measurement,

- Experimentation.

Scientific research can be conducted by Kolb experimental cycle. [3]

The deduction method begins with the formulation of theoretical knowledge obtained mostly by studying abstract systems, and through their testing, new knowledge and experience are gained.

The Induction method is based on this experience. Its repeated observation (measurement) will lead to the formulation of general concepts, theories, and generalizations that explain past experiences and predict the system's future behavior.

Induction and deduction are used sequentially. [2] We begin with the question: "Why is something happening this way?" and induction leads us to a preliminary hypothesis. This hypothesis is accepted when it sufficiently satisfactorily explains the fact we are asking. By deduction, we then test this hypothesis as to whether it has general validity. Schematically, we can see it in Figure 1. [4]

The DEDUCTION

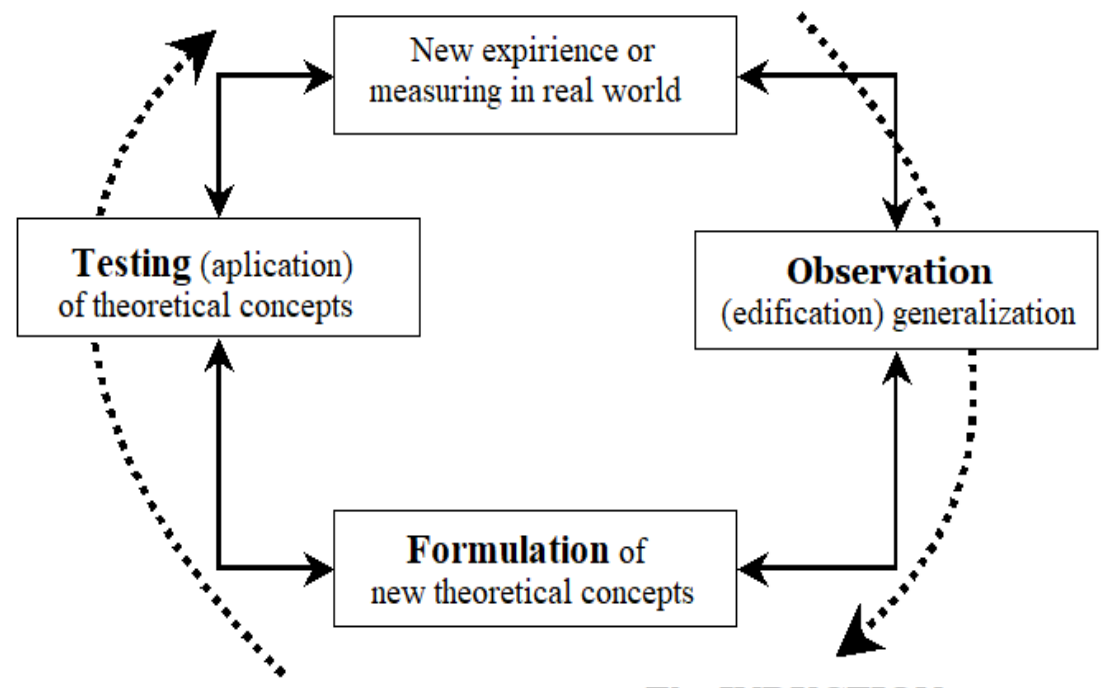

The INDUCTION

Fig. 1. Kolb's experimental cycle 
Occam's razor rule, i.e., a more straightforward explanation, is more likely to simplify problem-solving access and speed. When setting up analyses, you need to focus on factors that are important and dominant for decision-making.

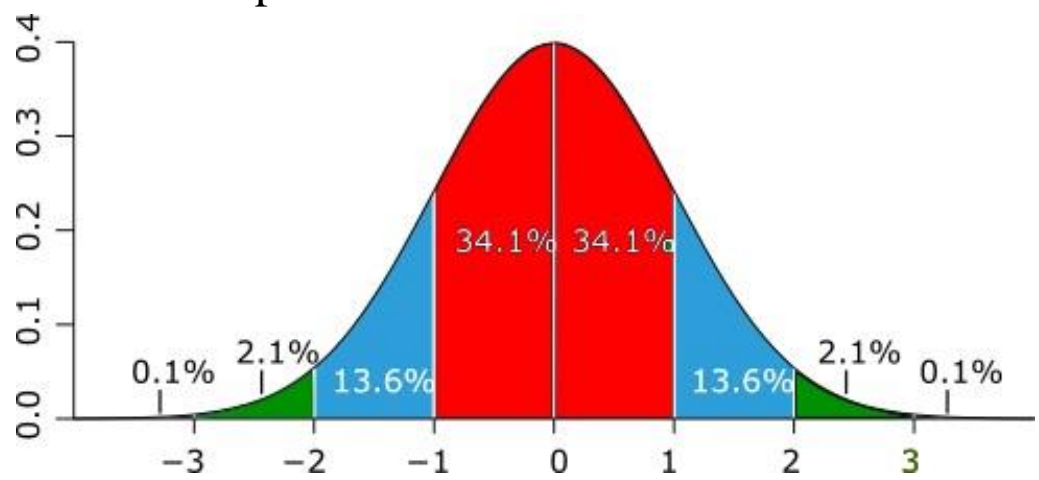

Chart 1 The Gauss distribution

The known Gauss distribution is the distribution of specific quantities into quartiles, which divide the statistical set into quarters of $25 \%$ in the horizontal axis. Even if we do not consider outside quartiles and only consider the central quartile, our hypotheses' accuracy will be within $68 \%$ probability. We can also apply this perspective to the property price and thus the licitation spread. [5]

\section{A. Valuation methods}

1. The usual (regular) price - is the price that would have been achieved in the sale of the same or similar assets or the provision of the same or similar service in the ordinary course of trade in the Czech Republic at the date of valuation. All circumstances affecting the price are considered. Still, we do not consider the market's extraordinary events, the seller or buyer's personal circumstances, or the sentimental value are not reflected. Extraordinary market circumstances mean, for example, the state of emergency of the seller or buyer, the consequences of natural or another calamity. Personal circumstances are property, family, or other personal relationships between the seller and the buyer. Special (sentimental) value means the influence of a bond between the seller with the tangible property or service. The usual price expresses the value of the thing and is determined by comparison.

2. Extraordinary price means the price to which the market's extraordinary circumstances, the seller or buyer's circumstances, or the influence of sentimental value were reflected.

\section{Price determined (by price regulation)}

The price determined by applicable regulations in the Czech Republic, under Act No. 151/1997 Coll., on assets' valuation. [7] It shall apply where the competent authority provides within the framework of its authorization or if parties to a contract agreed.

a) The cost method is based on the costs to acquire the valuation item at the place of valuation and according to its condition at the valuation date.

b) A revenue method calculates the yield's value generally obtained from the valuation's subject-matter under the given conditions. 
c) a comparative method is based on a comparison of the subject-matter of the valuation with the same or similar object, and the price agreed at the time of its sale; it is also the valuation of the item by deriving from the price of another functionally related item,

d) nominal value - is based on the stated or known price of the object of the valuation.

e) Book value — is based on valuation methods established based on accounting rules.

f) Exchange rate value - is based on the price recorded in the specified period on the regulated market.

4. The price agreed, the parties to the transaction have the freedom to negotiate prices unless the legal or price regulations provide otherwise. The price agreed for the transaction means an objective fact which expresses the consideration agreed upon by the parties for the assets transferred. [1]

\section{B. HYPOTHETICAL INFORMATION ABOUT REAL ESTATE}

To create the licitation spread and calculate from the abstract data, we need to specify and indicate the real method of calculating and determining its value. We will use actual values. For example, we will choose a hypothetical usual family house, which is in Prague.

\section{B.1 Localization of the property}

The hypothetical property we will be exploring is located $4 \mathrm{~km}$ west of Prague's center as the crow flies. We consider an imaginary family house with a convenient location. Ruzyně Airport is 9 kilometers by car. The Břevnov Monastery is about $250 \mathrm{~m}$ through the main road leading to the airport as the crow flies, on foot, it is about $600 \mathrm{~m}$. Prague Castle is 4 kilometers on foot. There are two metro stations, Motol station, and Petřiny station, at about two kilometers on foot.

\section{B.2 Description of the property}

We assume that the construction of the family house was completed sometime around 1930. The most critical structural elements are original, so the end-of-life span of the building is approaching. The concrete foundations are cracking. The wall is soaked, moldy. The family home lacks drainage and proper insulation against water. Cracks appear in the structures, but on the first look, the house seems flawless. Compared to the surrounding houses, it has a nice outside façade. However, inside the damp, mold, and insufficient insulation. In the family house, there are two apartment units. The usable area is $262 \mathrm{~m}^{2}$, the total built-up cubicle of the family house is $994.63 \mathrm{~m}^{3}$. Suppose that the building envelope area is $460 \mathrm{~m}^{2}$.

The building's energy performance is $352 \mathrm{MWh} / \mathrm{year}$ and is classified in category E (as wasteful). The building does not comply with Act No. 406/2000 Coll., on Energy Management. [9] The brick perimeter walls are $45 \mathrm{~cm}$ in width; from the original relief of the façade, I deduce that there is no insulation. Despite the gas heating, it is necessary to heat the rooms in the second store by direct 
heating in winter. According to the audit, the exterior walls and windows are to be dealt with. The state of the internal wiring is not known. There is an increased cost of energy consumption.

\section{CALCULATION OF THE PRICE OF REAL ESTATE}

The valuation of the property is carried out under Act No. 151/1997 Coll. on the Valuation of Assets and by Decree of the Ministry of Finance No. 441/2013 Coll., on the implementation of the Valuation Act (hereinafter referred to as the "OV") [8] considering the suitable correction of the author, who makes estimates of real estate according to this Decree as stated in his trade license.

\section{B.3 Determining the price of a family house by cost}

Cost method - based on the costs that would have to be incurred to re-acquire the subject of the valuation at a given place and time of valuation or to replace it with an object of equal usable value under its condition. Existing wear and tear and impairment of assets, i.e., cost (time) price / in-kind price $=$ replacement (new) price - wear and tear, is deducted from the costs of re-purchase (reproduction) or replacement of the property. The cost method provides a reliable indicator of the value of assets in a stabilized economic environment. The cost of acquiring an asset corresponds to the revenues that the asset can produce.The in-kind value of the real estate is determined by calculation using indicators per unit of measure. Indicators determine the average cost per unit of measure (built-in space). This amount is adjusted using coefficients that consider the differences between the valued property and the average sample. Furthermore, an amount equal to the amount of wear and tear of the property under-assessed is deducted.

The methodology is based on technical and economic indicators. This way, we can determine the value of buildings. It is necessary to add the land and accessories' value based on the building land's average prices in the locality to the previously calculated value. The usual price is derived by comparison from the comparable prices available. The value of the land is added to the price of the construction and accessories. The value of the real estate is the sum of the values of individual properties. The distribution and quantity of the built-up space can be seen from the project documentation. The property is not in satisfactory technical condition. Wear is estimated at a rate of about 50\%. The building's age is $90-100$ years, and some elements have their lifespan and will need to be replaced entirely.

The size of the built-up space is multiplied by the minimal price and subsequently adjusted and corresponding coefficients (these coefficients reflect the technical parameters of buildings, the location of buildings, but also, e.g., moral wear). Furthermore, a write-down due to technical wear is applied. To the resulting value for constructing buildings, the appraiser's value adds the estimated value of other accessories of buildings and land.

The real estate also includes the land under the building. Buildings partly cover the land; there are paved areas on other parts, and there is a small garden.

The determination of the price of land already built up in a stabilized location is based on price maps of land, which is CZK $12700 / \mathrm{m}^{2}$. It could also be found on 
the indexation method and the share of the land value in the value of the whole property. This method is used on a larger scale when we do not know the land price and know the value of the building, but here it is the opposite, we see the price of the land, and we calculate the family house price.

Valuation according to $\S 10 \mathrm{OV}$ - Valuation of the building in a costeffective manner

\section{$\mathbf{C S}=\mathbf{C S}_{\mathbf{N}} \times \mathbf{p p}$}

$\mathrm{CS}=$ price of the building

$\mathrm{CS}_{\mathrm{N}}=$ cost (price) of the construction

$\mathrm{pp}=$ coefficient of the adjustment of the price by location and market

\section{Valuation according to $§ 13 \mathrm{OV}$ - Family house, \\ $\mathrm{ZCU}=\mathbf{Z C} \times \mathrm{K}_{\mathbf{4}} \times \mathrm{K}_{\mathbf{5}} \times \mathrm{K}_{\mathrm{i}}$}

By Act No. 151/1997 Coll. on the Valuation of Assets, the ratio of individual structural elements to the property's price is given.

\begin{tabular}{|l|l|l|l|l|l|}
\hline & Element & & Status & Correction & Share \\
\hline 1 & Concrete foundations & 0,043 & Under & 0,46 & 0,02 \\
\hline 2 & $\begin{array}{l}\text { Vertical construction of masonry } 45 \mathrm{~cm} \\
\text { in width }\end{array}$ & 0,243 & Under & 0,46 & 0,112 \\
\hline 3 & Ceilings & 0,093 & included & 1 & 0,093 \\
\hline 4 & Roofing wooden truss & 0,042 & included & 1 & 0,042 \\
\hline 5 & Roof coverings asphalt shingles & 0,03 & included & 1 & 0,03 \\
\hline 6 & Tinsmith structures - zinc & 0,007 & included & 1 & 0,007 \\
\hline 7 & Inner plaster & 0,064 & included & 1 & 0,064 \\
\hline 8 & Façade plasters & 0,033 & included & 1 & 0,033 \\
\hline 9 & Exterior tiles - ceramic & 0,004 & included & 1 & 0,004 \\
\hline 10 & Interior tiles - ceramic & 0,024 & included & 1 & 0,024 \\
\hline 11 & Stairs & 0,039 & included & 1 & 0,039 \\
\hline 12 & Doors - doorframes, wooden doors & 0,034 & included & 1 & 0,034 \\
\hline 13 & Wooden windows, caste & 0,053 & Under & 0,46 & 0,024 \\
\hline 14 & Floors of living rooms & 0,023 & included & 1 & 0,023 \\
\hline 15 & Other rooms & 0,014 & included & 1 & 0,014 \\
\hline 16 & Heating - gas & 0,042 & included & 1 & 0,042 \\
\hline 17 & Wiring & 0,04 & included & 1 & 0,04 \\
\hline 18 & Lightning rod & 0,005 & Included & 1 & 0,005 \\
\hline 19 & Water distribution & 0,028 & included & 1 & 0,028 \\
\hline
\end{tabular}




\begin{tabular}{|l|l|l|l|l|l|}
\hline 20 & Hot water source & 0,016 & included & 1 & 0,016 \\
\hline 21 & Gas installation & 0,005 & Included & 1 & 0,005 \\
\hline 22 & Drain & 0,029 & Included & 1 & 0,029 \\
\hline 23 & Kitchen equipment & 0,005 & Included & 1 & 0,005 \\
\hline 24 & Inner hygienic equipment & 0,05 & Included & 1 & 0,05 \\
\hline 25 & Toilet & 0,004 & Included & 1 & 0,004 \\
\hline 26 & Other & 0,03 & NO & 0 & 0 \\
\hline Total & 1 & & & 0,787 \\
\hline
\end{tabular}

Table lof construction and equipment.

ZC = base price in CZK per $\mathbf{m}^{3}$ of the built-up building space according to Annex No. 11 OV, according to Table 1 and Table 2

$\mathrm{ZC}=$ type $\mathrm{D}=1,900,-\mathrm{CZK} / \mathrm{m}^{3}$

$\mathrm{ZC}=$ type $\mathrm{C}=1,900,-\mathrm{CZK} / \mathrm{m}^{3}$

$\mathrm{x}$ coefficient from Table $2=1,075$

$\mathrm{ZC}=1,900 \times 1,075=2,042.50 \mathrm{CZK}$

$\mathrm{K}_{4}=$ coefficient of construction equipment according to Annex No 21, Table 3 of the $\mathrm{OV}$

$\mathrm{K}_{4}=1+(0.54 \times \mathrm{n})$

$\mathrm{n}=$ sum of the price shares of structures and equipment

$\mathrm{K}_{4}=0.787$

$\mathrm{K}_{5}=$ position coefficient according to Annex No $20 \mathrm{OV}$, table 1 item 1

$\mathrm{K}_{5}=$ other statutory cities $=1.25$

$\mathrm{K}_{\mathrm{i}}=$ coefficient of change in construction prices according to Annex No 41 OV 112146.21 .11 .2

$\mathrm{K}_{\mathrm{i}}=2,250$

\begin{tabular}{|l|l|l|l|l|l|}
\hline & $\mathrm{Zc}$ & $\mathrm{K}_{4}$ & $\mathrm{~K}_{5}$ & $\mathrm{~K}_{\mathrm{i}}$ & $\mathrm{ZCU}$ \\
\hline $\mathrm{Rd}$ & $2.042,50$ & 0,787 & 1,25 & 2,250 & 4502,95 \\
\hline
\end{tabular}

Table 2 of the $\mathrm{ZCU}$

$$
\boldsymbol{Z C U}=\mathrm{CZK} 4502.95 / \mathrm{m}^{3}
$$

Wear

According to $\S 30 \mathrm{OV}$ Wear, a simplified modified linear method is determined according to Annex No. $21 \mathrm{OV}$.

For wear and tear purposes, the year of completion of 1930 is considered, so its age of the house is about 90 years. The expected lifespan for single-family houses is expected to be 100 years. Due to the repair of some elements, the lifespan is partially extended. On the contrary, the façade, although it looks preserved from the outside, will have to be made again due to the need for thermal insulation. 
Wear of the house is determined by the linear method at $50 \%$.

Wear of the house is $50 \%$

$$
\begin{aligned}
& K_{O P}=(100-70) / 100=0.5 \\
& C S=C_{N} \times p p=C_{N} \times I_{T} \times I_{P}
\end{aligned}
$$

Market Index

\begin{tabular}{|c|c|}
\hline \multicolumn{2}{|l|}{$I_{T}=P 6 \times x P 7 \times P 8 \times P 9 \times(1+\Sigma p i)$} \\
\hline Demand higher & $\begin{array}{l}0,0 \\
6\end{array}$ \\
\hline land in co-ownership & 0 \\
\hline $\begin{array}{l}\text { changes in the surrounding area - } \\
\text { without influence }\end{array}$ & 0 \\
\hline legal relations & \\
\hline $\begin{array}{l}\text { without further influences, it is } \\
\text { necessary to warm up }\end{array}$ & $\begin{array}{c}0,0 \\
2\end{array}$ \\
\hline Zone 1 & 1 \\
\hline Importance of the municipality & 1.2 \\
\hline location of the municipality & $\begin{array}{l}1,1 \\
5\end{array}$ \\
\hline $\begin{array}{l}\text { amenities of the municipality - } \\
\text { complex }\end{array}$ & 1 \\
\hline$\Gamma$ & $\begin{array}{l}1,4 \\
4\end{array}$ \\
\hline
\end{tabular}

- Annex No 3, Table 1 of the OV

Table No. 3 Calculation $I_{T}$

Kick $=0.3$

$$
\begin{aligned}
& I_{T}=1.44 \\
& I_{P}=1.14
\end{aligned}
$$

\begin{tabular}{|c|c|c|}
\hline \multicolumn{3}{|c|}{$I_{P}=P_{1} \times(1+\Sigma p i)$} \\
\hline & $\begin{array}{l}\text { residential, municipality } \\
\text { over } 2000 \mathrm{ob}\end{array}$ & 1 \\
\hline & $\begin{array}{l}\text { Predominant development - } \\
\text { residential }\end{array}$ &, 0 \\
\hline & Location in the village & 0 \\
\hline & Network connection option & \\
\hline & Civic amenities & 0 \\
\hline & $\begin{array}{l}\text { Transport } \\
\text { accessibility }\end{array}$ & $\begin{array}{l}0,0 \\
1\end{array}$ \\
\hline & Public transport, Metro & $\begin{array}{l}0,0 \\
3\end{array}$ \\
\hline & Bargain & 0 \\
\hline & Population - trouble-free & 0 \\
\hline 0 & Unemployment - average & 0 \\
\hline 1 & $\begin{array}{l}\text { Influences other - Prague } \\
\text { capital }\end{array}$ & $\begin{array}{l}0,0 \\
3\end{array}$ \\
\hline & $\mathrm{Pi}$ & $\begin{array}{l}0,1 \\
4\end{array}$ \\
\hline & & 1,1 \\
\hline
\end{tabular}

Position index - Annex No 3, Table 3 of the OV

Table No. 4 Calculation $I_{P}$ 
Calculation of price without wear new building Kop $=1$

\begin{tabular}{|l|l|l|l|l|l|}
\hline & ZCU & Kick & $\boldsymbol{I}_{\boldsymbol{T}}$ & $\boldsymbol{I}_{\boldsymbol{P}}$ & ZCU \\
\hline $\operatorname{Rd}$ & 4502,95 & 1 & 1,03 & 1,14 & $\mathbf{5 2 8 7 , 3 6}$ \\
\hline
\end{tabular}

Table 5 adjusted $\mathrm{ZCU}$ without wear

Price determined without wear $=\mathrm{CS} \times \mathrm{m}^{3}=5287.36 \times 994.63=5,258,970,-\mathrm{CZK}$

\begin{tabular}{|l|l|l|l|l|l|}
\hline & ZCU & Kick & $\boldsymbol{I}_{\boldsymbol{T}}$ & $\boldsymbol{I}_{\boldsymbol{P}}$ & ZCU \\
\hline $\operatorname{Rd}$ & 4502,95 & 0,5 & 1,03 & 1,14 & $\mathbf{2 6 4 3 , 6 8}$ \\
\hline
\end{tabular}

Table 6 of adjusted $\mathrm{ZCU}$ with wear and tear

Price found $=$ CS x m ${ }^{3}=2643.68 \times 994.63=2,629,485,-$ CZK

\section{B.4 Determining the price of a family house by comparison}

Comparison method (market comparison approach) - is based on comparing the subject of valuation with the same or similar items and the prices achieved during their sales. It may also be an appreciation of a thing by deriving from the price of another functionally related thing.

The comparison method is most used and usually preferred. It is quite accurate, and, in many cases, it is very close to the real estate's real value. This method is based on a comparison of valued real estate with a selected sample of real estate with similar parameters and is or has already been traded on the real estate market. When using this method, it is essential to select samples, which should approach the valued property by their parameters. The comparison is then based either on some well-identifiable and telling unit of measure (quantitative analysis), nor the property is assessed by qualitative research.

A method of comparing indirect with a group of similar selected real estate for which, using comparative coefficients and adjustments, the price is adjusted to the flat price and then recalculated to the valued property's price using the weighted average. As a comparison unit of measure, I have determined the area of the plot.

The valued properties consist of family houses with accessories and land. The real estate is valued. By comparison, it is assessed with comparable real estate from the surrounding municipalities. In this case, these are RD properties in the broader center of Prague.

The main price comparison coefficients include (a type of transaction, location, technical factors, economic factors, number of floors, use of real estate, non-real estate factors, legal relationships). As a specific comparison unit, the usable area that carries the value of the property is determined.

We need to summarize all available information about other properties sold with similar parameters in a similar location. There are several properties on offer in Prague in Prague's broader center, the offer price of which ranges from CZK 9- 
16 million (different sizes). Since these are bid prices, these prices are reduced by 10-30 $\%$ due to the assumption of a price reduction during the price negotiations or the length of time for which the property is offered. In the direct sale, the price of the commission is withered to the real estate agency. However, this method has a disadvantage; it is difficult to know how much the property is sold.

The Ministry of Finance has more information about this matter. It would be advisable to include this information in the new version of the Decree of the Ministry of Finance No. 441/2013 Coll. on implementing the Valuation Act. The price increases with proximity to tourist and visitor sites. Residential areas near city centers are priced higher, thanks to prestige and proximity to full civic amenities and work opportunities. Another factor is whether the property is in the street part or is a corner building. Such property has a higher value than a terraced property or the one in a yard and atrium.

In the first table, we will quantitatively specify the property as much as possible to approach the real conditions for comparison. In the second table, we will deal with the property qualitatively.

\begin{tabular}{|c|c|c|c|c|c|c|}
\hline Subject of award & $\begin{array}{l}\text { Family house } \\
\text { in question }\end{array}$ & $1[11]$ & $2[11]$ & $3[11]$ & $4[11]$ & $5[11]$ \\
\hline Site designation & Prague 6 & $\begin{array}{l}\text { Prague } 6 \\
\text { Vokovice } \\
1\end{array}$ & $\begin{array}{l}\text { Prague } \quad 6 \\
\text { Vokovice } 2\end{array}$ & $\begin{array}{l}\text { Prague } \\
\text { Břevnov }\end{array}$ & $\begin{array}{lll}\text { Prague } & 6 & - \\
\text { Repy } & & \end{array}$ & \begin{tabular}{|ll} 
Prague & 6 \\
Repy &
\end{tabular} \\
\hline Transaction date & IV.20 & II.19 & IV.20 & from $2 / 20$ & IV.20 & from $12 / 20$ \\
\hline Transaction type & & Offer & Offer & Offer & Offer & Offer \\
\hline Floor & $2+$ attic & $1+$ attic & $3+$ attic & $2+$ attic & 2+attic & $2+$ attic \\
\hline Number of floors & basement & cellar & 1 & basement & 1 & basement \\
\hline Construction: & Brick & Brick & Brick & Brick & Brick & Brick \\
\hline Area of land: & 406 & 380 & 380 & 379 & 150 & 361 \\
\hline Built-up area & 95 & 87 & 99 & 120 & 99 & 206 \\
\hline Building + land & & $\begin{array}{ll}19 & 500 \\
000 & \\
\end{array}$ & 19500000 & 18200000 & 12400000 & 12900000 \\
\hline Correction per offer & & $10 \%$ & $10 \%$ & $10 \%$ & $10 \%$ & $10 \%$ \\
\hline $\begin{array}{l}\text { With the cost of } \\
\text { transactions }\end{array}$ & & $10 \%$ & $10 \%$ & & $10 \%$ & \\
\hline $\begin{array}{l}\text { Building }+ \text { land } \\
(\mathrm{CZK})\end{array}$ & & 15600000 & 15600000 & 16380000 & 9920000 & 11610000 \\
\hline $\begin{array}{l}\text { Value of } \mathrm{m}^{2} \text { of land } \\
\text { (CZK) }\end{array}$ & 12700 & 12700 & 12700 & 12700 & 12700 & 12700 \\
\hline $\begin{array}{l}\text { Deduction of the } \\
\text { value of the land }\end{array}$ & 5156200 & 4826000 & 4826000 & 4813300 & 1905000 & 4584700 \\
\hline $\begin{array}{ll}\text { Price } & \text { of } \\
\text { construction } & \end{array}$ & & 10774000 & 10774000 & 11566700 & 8015000 & 7025300 \\
\hline Number of units: & 262 & 300 & 322 & 332 & 375 & 206 \\
\hline Price per unit & & 35913 & 33460 & 34839 & 21373 & 34103 \\
\hline
\end{tabular}




\begin{tabular}{|l|l|l|l|l|l|l|}
\hline 1. Attractiveness of the site & Excellent & Similar & Similar & Similar & Worse & Similar \\
\hline relative adjustment & & $0 \%$ & $0 \%$ & $0 \%$ & $10 \%$ & $0 \%$ \\
\hline 2. Transport accessibility & $\begin{array}{l}\text { very } \\
\text { good }\end{array}$ & Similar & Similar & Similar & Similar & Similar \\
\hline relative adjustment & & $0 \%$ & $0 \%$ & $0 \%$ & $0 \%$ & $\%$ \\
\hline $\begin{array}{l}\text { 3. } \text { External part of the building } \\
\text { relative adjustment }\end{array}$ & $\begin{array}{l}\text { very } \\
\text { good }\end{array}$ & Worse & Similar & Similar & Worse & Similar \\
\hline $\begin{array}{l}\text { 4. Interior part of the building and } \\
\text { equipment }\end{array}$ & very & $10 \%$ & $0 \%$ & $0 \%$ & $10 \%$ & $0 \%$ \\
\hline good & Worse & Similar & Worse & Worse & Similar \\
\hline $\begin{array}{l}\text { 6. Infrastructure-network } \\
\text { water) }\end{array}$ & $10 \%$ & $0 \%$ & $10 \%$ & $10 \%$ & $0 \%$ \\
\hline relative adjustment & yes/yes & yes/yes & yes/yes & yes/yes & yes/yes & yes/yes \\
\hline 6. Infrastructure-networks (gas, sewer) & yes/yes & yes/yes & yes/yes & yes/yes & yes/yes & yes/yes \\
\hline relative adjustment & & $0 \%$ & $0 \%$ & $0 \%$ & $0 \%$ & $0 \%$ \\
\hline $\begin{array}{l}\text { 7. Limited property rights } \\
\text { relative adjustment }\end{array}$ & No & Similar & Similar & id $1 / 2$ & Similar & Similar \\
\hline price before correction & $20 \%$ & $0 \%$ & $10 \%$ & $30 \%$ & $0 \%$ \\
\hline $\begin{array}{l}\text { Adjusted price per unit } \\
\text { CZK }\end{array}$ & $\mathbf{3 5 9 1 3}$ & 33460 & 34839 & 21373 & 34103 \\
\hline
\end{tabular}

Figure 1 Qualitative correction

Average utility area price per $\mathrm{m}^{2}$

$\mathrm{PCUP}=(28730+33460+27871+14961+34103) / 5=\mathbf{2 7 8 2 5} \mathbf{C Z K} / \mathbf{m}^{2}$

\begin{tabular}{|l|l|l|l|l|l|}
\hline \multicolumn{1}{|c|}{ Pn } & \multicolumn{1}{c|}{1} & \multicolumn{1}{c|}{2} & \multicolumn{1}{c|}{3} & \multicolumn{1}{c|}{4} & \multicolumn{1}{c|}{5} \\
\hline \multirow{3}{*}{ CZN } & CZK & CZK & CZK & CZK & CZK \\
\hline \multirow{3}{*}{ CSP } & $7,527,365$ & $8,766,520$ & $7,302,254$ & $3,919,808$ & $8,934,986$ \\
\hline \multirow{3}{*}{ total price } & CZK & CZK & CZK & CZK & CZK \\
\hline & $12,156,200$ & $5,156,200$ & $5,156,200$ & $5,156,200$ & $5,156,200$ \\
\hline
\end{tabular}

Table No. 8 -Price of the property under sale recalculated from several offers

PN - Comparison property 
PCZN - Recalculated the price of the property under question

$\mathrm{CZP}$ - Price of the land under survey

\section{B.5 Determining the price of a family house by yield method}

The return method (yield method) is based on the returns of the subject of the valuation achieved or the revenues that can usually be obtained from the subject of the valuation under the given conditions. These revenues are discounted or capitalized at the valuation date. The yield method is mainly used for commercial real estate rentals. The yield methodology considers the property's price by its profitability in its life cycle and thus its factual purpose for the owner. Investors and owners buy real estate for various purposes, including housing and relaxation, others for investment and business plans. The yield method's basis and inputs are the financially quantified values that the property brings to the owner/user. Other operands in the calculation are the costs that the operation and maintenance of the property entail. After the income and costs are calculated, we can calculate the property's net monthly/annual yield. We will then transfer this one using the capitalization rate and find out the property's price by using the yield methodology. The capitalization rate considers inflationary effects, opportunity investment opportunities, risk levels, and other economic indicators that affect the capitalization rate's upward or downward size.

The calculation of the yield value of the property is based on the rental income of the property. In our case, it is used as a residential building for renting residential space. For the calculation, the valuer used the usually achieved monthly rent, which depends mainly on the usable area, the condition of the property, lucrativeness, and location.

There are available areas with about $224 \mathrm{~m} 2$ of space in the building, which we can consider for monthly rent. In the future, we assume rent of 223 $\mathrm{CZK} / \mathrm{m}^{2}$. Today we set $135 \mathrm{CZK} / \mathrm{m}^{2}$ in the calculation. Rent is considered at a lower level. The revenue rates are thus determined to correspond to the expected usual returns on the given location's real estate market.

Due to the site's technical condition, character, and lucrative nature, we estimate the potential risk of revenue shortfalls of 5-10\% when rents increase. To calculate regular annual costs, the author estimates these costs. The capitalization rate is set by expert estimates considering inflationary effects, interest rates, the level of risk, and the property's characteristics, including its location in a variant between $4-6 \%$.

Due to lower interest rates and low money prices, and the availability of finance in the financial market, these rates are currently at historic lows. Simultaneously, it is a building in a good location, where there is an assumption of a lower risk of investing in this property and a very low probability of loss of value. The real estate is not in good technical condition. For further and trouble-free rental, it is necessary to make significant construction modifications. 


\begin{tabular}{|c|c|c|c|}
\hline Replacement price & $\begin{array}{c}\text { CZK } \\
10,415,171\end{array}$ & & \\
\hline & & Existing & Potential \\
\hline $\begin{array}{l}\text { The monthly yield on rent under } \\
\text { consideration. }\end{array}$ & & $30,506 \mathrm{CZK}$ & $50,000 \mathrm{CZK}$ \\
\hline Potential gross annual return on real estate & & CZK 366,072 & $600,000 \mathrm{CZK}$ \\
\hline An estimate of rent shortfall \% & 10 & & 60,000 CZK \\
\hline Effective gross annual return & & CZK 366,072 & $\$ 20,000$ \\
\hline Property tax estimate & & 2,069 CZK & 2,069 CZK \\
\hline Real estate insurance estimate & 3,500 CZK & 3,500 CZK & $3,500 \mathrm{CZK}$ \\
\hline Property management estimate & & $5,000 \mathrm{CZK}$ & $5,000 \mathrm{CZK}$ \\
\hline Operating costs estimate & $5,000 \mathrm{CZK}$ & $5,000 \mathrm{CZK}$ & $5,000 \mathrm{CZK}$ \\
\hline Repair Fund & $0,25 \%$ & $30,000 \mathrm{CZK}$ & CZK $\quad 30,000$ \\
\hline Net annual revenue & & 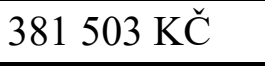 & $494431 \mathrm{Kč}$ \\
\hline \multirow[t]{3}{*}{ Determination of the capitalization rate $\%$} & 4 & $\begin{array}{l}\text { CZK } \\
9,537,575 \\
\end{array}$ & $\begin{array}{l}\text { CZK } \\
12,360,775\end{array}$ \\
\hline & 5 & $\begin{array}{l}\text { CZK } \\
7,630,060\end{array}$ & CZK 9,888,620 \\
\hline & 6 & $\begin{array}{l}\text { CZK } \\
6,358,383\end{array}$ & CZK 8,240,517 \\
\hline
\end{tabular}

Table No. 8 Yield method.

The price of the property using the yield method is CZK 9,619,322.

\section{B.6 Land}

Price map of land in Prague as of January 2, 2021[10] map sheet 44, parcel group 2560, the land price is set at CZK $12700 / \mathrm{m}^{2}$.

The hypothetically determined area of land is $406 \mathrm{~m}^{2}$ in total.

Land price $=406 \times 12700=5.156 .200,-$ CZK

\section{CONCLUSION, THE LICITATION SPREAD PRICE} ESTABLISHED

\section{Property price is determined in several ways.}

\begin{tabular}{|l|l|l|}
\hline 1 & Land price determined from price map & CZK 5,156,200 \\
\hline 2 & Cost method without land for 80 years & CZK 2,629,486 \\
\hline 3 & Cost method of the new house without land & CZK 5,258,971 \\
\hline 4 & Cost method 80 years old house with land & CZK 7,785,686 \\
\hline 5 & Cost method new house with land & CZK 10,415,171 \\
\hline 6 & Average house price (by yield method) & CZK 9,002,655 \\
\hline 7 & $4 \%$ capitalization of existing rent & CZK 9,537,575 \\
\hline
\end{tabular}




\begin{tabular}{|l|l|l|}
\hline 8 & $5 \%$ of the capitalization of the existing rent & CZK 7,630,060 \\
\hline 9 & $6 \%$ of the capitalization of the existing rent & CZK 6,358,383 \\
\hline 10 & $4 \%$ capitalization increased rent & CZK 12,360,775 \\
\hline 11 & $5 \%$ capitalization increased rent & CZK 9,888,620 \\
\hline 12 & $6 \%$ capitalization increased rent & CZK 8,240,517 \\
\hline 13 & Comparison pattern - house No.1 & CZK 12,683,565 \\
\hline 14 & Comparison pattern - house No.2 & CZK 13,922,720 \\
\hline 15 & Comparison pattern - house No.3 & CZK 12,458,454 \\
\hline 16 & Comparison pattern - house No.4 & CZK 9,076,008 \\
\hline 17 & Comparison pattern - house No.5 & CZK 14,091,186 \\
\hline & Average & CZK 10,054,099
\end{tabular}

\section{Table 9 determination of the property's values in several ways}

In the case of price determination, the author is inclined towards the resulting usual price of real estate, which oscillates around the average calculated value, which is the price of CZK 10,054,099.

The cost and revenue methods have similar valuation results. The comparison method has higher results.

The results suggest an older, lucrative location, but the construction requires considerable investment to meet the escalating energy requirements and greater demands on modern housing. The property is near the center of Prague, with good access to public transport.

The methods mentioned earlier (if there is sufficient data) are usually used to calculate and estimate the usual price, the comparison method being the primary method. Usually, the closest to the actual market value and, consequently, the achieved and realized sales prices. This method indicates the market environment and the specific supply of real estate the most. State methods tend to be controlled and, in most cases, draw certain constraints and price level limits. Simultaneously, if the deviations of the methods used are not too high, it is possible to lean towards the results of the comparison method. The shortcoming of this method is that real estate agencies sometimes overvalue real estate by more than $30 \%$. You can watch how long the property is on offer. Overvaluation results from $10 \%$ of the real estate agent's commission, and they also have a 10-20\% reserve for a discount. When a property is offered for more than two months, I will make a $10 \%$ price reduction.

Should the derogations be more significant, it is necessary to carry out a more in-depth analysis of such differences, involve several aspects of the survey, and determine the resulting market value with caution and appropriate, considering the results of other methods. When the property is older, it is necessary to lean towards the yield method and make a qualified estimate between the yield and comparison methods, considering the cost method's age and condition. 
In some cases, the price of the older properties is determined only by the land price on the price map of Prague (Czech capital city). When older properties are unsatisfactory, the cost of demolishing the building goes into millions of CZK.

Considering the calculations and analyses carried out, I believe that the price level of the assets is in the approximate range: from CZK 8 million to CZK 14 million. This is called the licitation spread.

\section{Licitation spread}

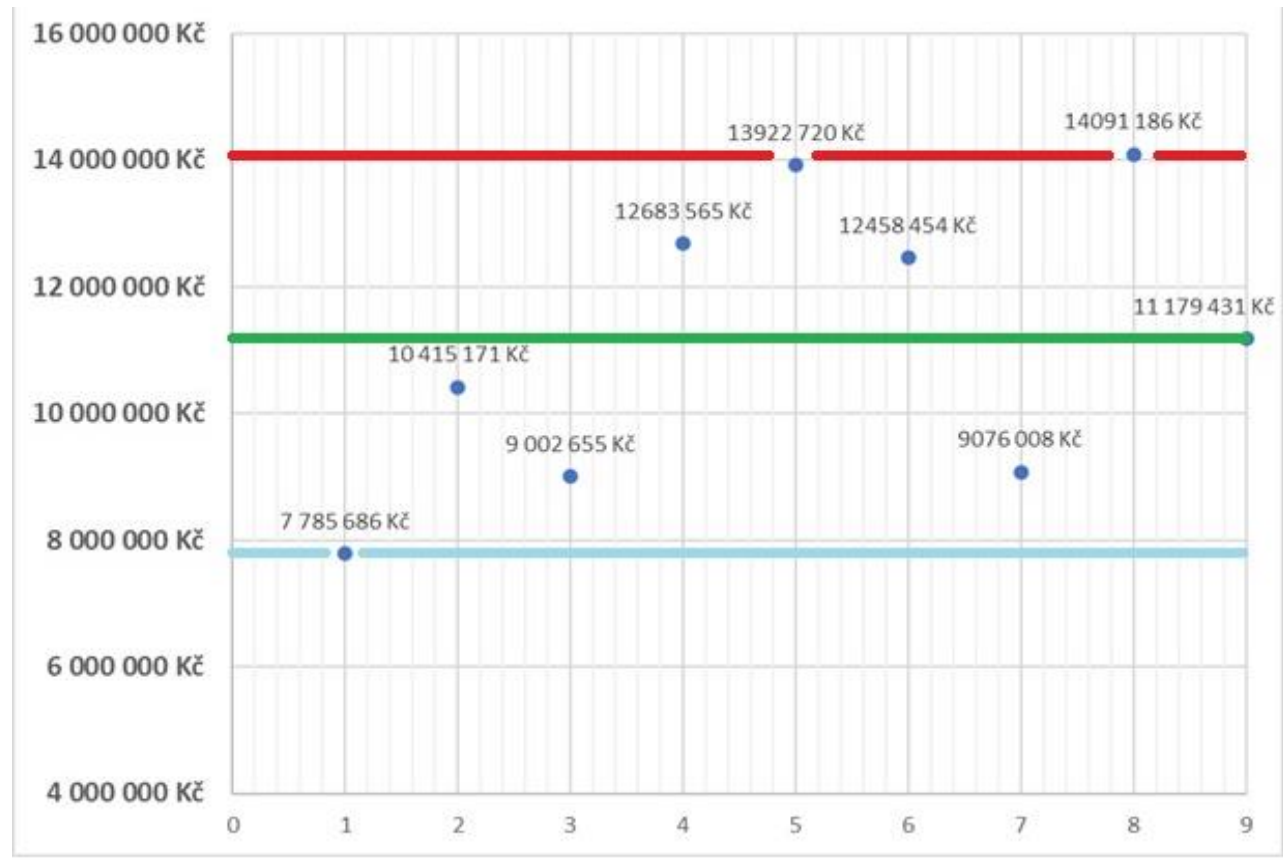

Chart 1 Licitation spread

Conclusion. Since the author of the article had sufficient samples of a similar nature when using the comparison method, adequate safety coefficients were applied, at the same time, a comparable value is given by the yield method, it is possible to base the comparison value and the valuer will consider it as corresponding to the market value.

From the available materials from the past, there is an increase in the usual prices of real estate. Due to the significant boom in the market in recent years, there has been an increase in the real estate value in good locations in Prague by order of 5-15\% per year. During the pandemic, residents rushed into real estate purchases. They want to ensure their savings, take advantage of low-interest rates, and save on the abolished transfer tax. The Czech Republic is thus experiencing the highest demand for mortgages in history. However, the Czech National Bank (CNB) comes with a warning that apartments and houses' prices are often overvalued by up to a quarter. And some banks also provide mortgages that clients cannot pay. The calculation reflects a $25 \%$ overpricing of the real estate market. It is also impossible to credibly determine how much the property was sold for. We can only correct it by a qualified estimate.

Therefore, we can state that the property's price is in the middle of the licitation spread. 


\section{References:}

1. NEDBÁLEK, K., Teoretické aspekty vzniku odpovědnosti za škodu při výkonu veřejné moci, jako predmět úpravy práva v konkrétním př́padě v ČR: Dizertační práce. Paneurópska vysoká škola v Bratislavě, fakulta práva, Ústav teoria a dejiny štátu a práva. Bratislava: 2012, $163 \mathrm{~s}$.

2. KOLB D, A., RUBIN, I. M. \& MCINTYRE, J. M., Organizational Psychology. An experimental Approach. 1979.

3. COOPER, DR \& EMORY, CW, Business Research Methods. 1995.

4. MOLNÁR, Z., MILDEOVÁ, S., ŘEZANKOVÁ, H., BRIXÍ, R., KALINA, J., Pokročilé metody védecké práce. 2012.

5. NEDBÁLEK, K., MALINOVÁ, N., Rej Masek, Kolokvium rozmluva ABOUT ALL. [společenská studie], Slušovice: Čibe a.s., advokátní kancelář K. Nedbálek, 2021. ISBN 978-80270-9202-4,

6. Zákon č. 151/1997 Sb., o oceňování majetku. (Czech Act No. 151/1997 Coll., on valuation of assets)

7. BRADÁČ, A. a kol., Úřední oceňování majetku 2019, Akademické nakladatelství CERM, srpen 2019, ISBN 978-80-7223-013-2.

8. Zákon č. 406/2000 Sb., o hospodaření energií (Czech Act No. 406/2000 Coll., on Energy Management)

9. Vyhláška MF č. 441/2013 Sb., k provedení zákona o oceňování.

(Czech Decree of the Ministry of Finance No. 441/2013Coll., on the implementation of the Valuation Act.

10. Ceny nemovitostí realitní kanceláre, [online]. [cit. 2021-01-13]. Available on the Internet: <https://www.sreality.cz>.

11. Cenová mapa stavebních pozemků hl města Praha k 2.1. 2021+ Price map of building land in Prague as of January 2, 2021 [online]. [cit. 2021-01-2]. Available on the Internet: <https://app.iprpraha.cz/apl/app/cenova-mapa/>. 